\title{
Emergency Medicine Milestones
}

The Accreditation Council for Graduate Medical Education

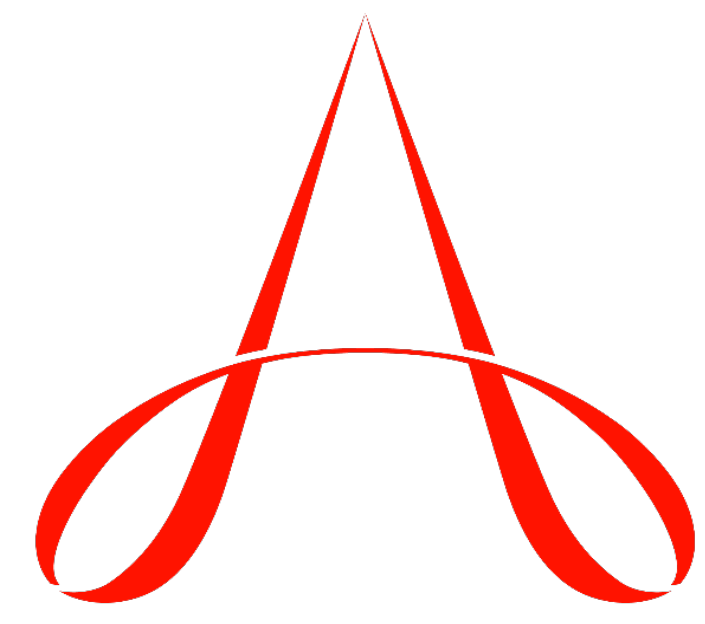

\section{A G G M E}

Implementation Date: July 1, 2021

Second Revision: February 2021

First Revision: December 2012 


\section{Emergency Medicine Milestones}

The Milestones are designed only for use in evaluation of residents in the context of their participation in ACGME-accredited residency programs. The Milestones provide a framework for the assessment of the development of the resident in key dimensions of the elements of physician competence in a specialty or subspecialty. They neither represent the entirety of the dimensions of the six domains of physician competency,

nor are they designed to be relevant in any other context. 


\title{
Emergency Medicine Milestones
}

Work Group

\author{
Michael Beeson, MD \\ Wallace Carter, MD \\ Robert Cooney, MD, MSMedEd \\ Laura Edgar, EdD, CAE \\ Jo Anna Leuck, MD \\ Valerie Lober, PhD
}
Douglas McGee, DO, FACEP
Tiffany Murano, MD
Donald Phillips, DO
Hope Ring, MD
Ryan Starr, DO

The ACGME would like to thank the following organizations for their continued support in the development of the Milestones:

\author{
American Board of Emergency Medicine \\ Association of American Medical Colleges \\ Council of Residency Directors in Emergency Medicine \\ Emergency Medicine Residents' Association \\ Review Committee for Emergency Medicine
}




\section{Understanding Milestone Levels and Reporting}

This document presents the Milestones, which programs use in a semi-annual review of resident performance, and then report to the ACGME. Milestones are knowledge, skills, attitudes, and other attributes for each of the ACGME Competencies organized in a developmental framework. The narrative descriptions are targets for resident performance throughout their educational program.

Milestones are arranged into levels. Tracking from Level 1 to Level 5 is synonymous with moving from novice to expert resident in the specialty or subspecialty. For each reporting period, the Clinical Competency Committee will review the completed evaluations to select the milestone levels that best describe each learner's current performance, abilities, and attributes for each subcompetency.

These levels do not correspond with post-graduate year of education. Depending on previous experience, a junior resident may achieve higher levels early in his/her educational program just as a senior resident may be at a lower level later in his/her educational program. There is no predetermined timing for a resident to attain any particular level. Residents may also regress in achievement of their milestones. This may happen for many reasons, such as over scoring in a previous review, a disjointed experience in a particular procedure, or a significant act by the resident.

Selection of a level implies the resident substantially demonstrates the milestones in that level, as well as those in lower levels (see the diagram on page vi). 


\section{Additional Notes}

Level 4 is designed as a graduation goal but does not represent a graduation requirement. Making decisions about readiness for graduation and unsupervised practice is the purview of the program director. Furthermore, Milestones 2.0 include revisions and changes that preclude using Milestones as a sole assessment in high-stakes decisions (i.e., determination of eligibility for certification or credentialing). Level 5 is designed to represent an expert resident whose achievements in a subcompetency are greater than the expectation. Milestones are primarily designed for formative, developmental purposes to support continuous quality improvement for individual learners, education programs, and the specialty. The ACGME and its partners will continue to evaluate and perform research on the Milestones to assess their impact and value.

Examples are provided for some milestones within this document. Please note: the examples are not the required element or outcome; they are provided as a way to share the intent of the element.

Some milestone descriptions include statements about performing independently. These activities must occur in conformity to ACGME supervision guidelines as described in the Program Requirements, as well as to institutional and program policies. For example, a resident who performs a procedure independently must, at a minimum, be supervised through oversight.

A Supplemental Guide is also available to provide the intent of each subcompetency, examples for each level, assessment methods or tools, and other available resources. The Supplemental Guide, like examples contained within the Milestones, is designed only to assist the program director and Clinical Competency Committee, and is not meant to demonstrate any required element or outcome.

Additional resources are available in the Milestones section of the ACGME website. Follow the links under "What We Do" at www.acgme.org. 
The diagram below presents an example set of milestones for one sub-competency in the same format as the ACGME Report Worksheet. For each reporting period, a resident's performance on the milestones for each sub-competency will be indicated by selecting the level of milestones that best describes that resident's performance in relation to those milestones.

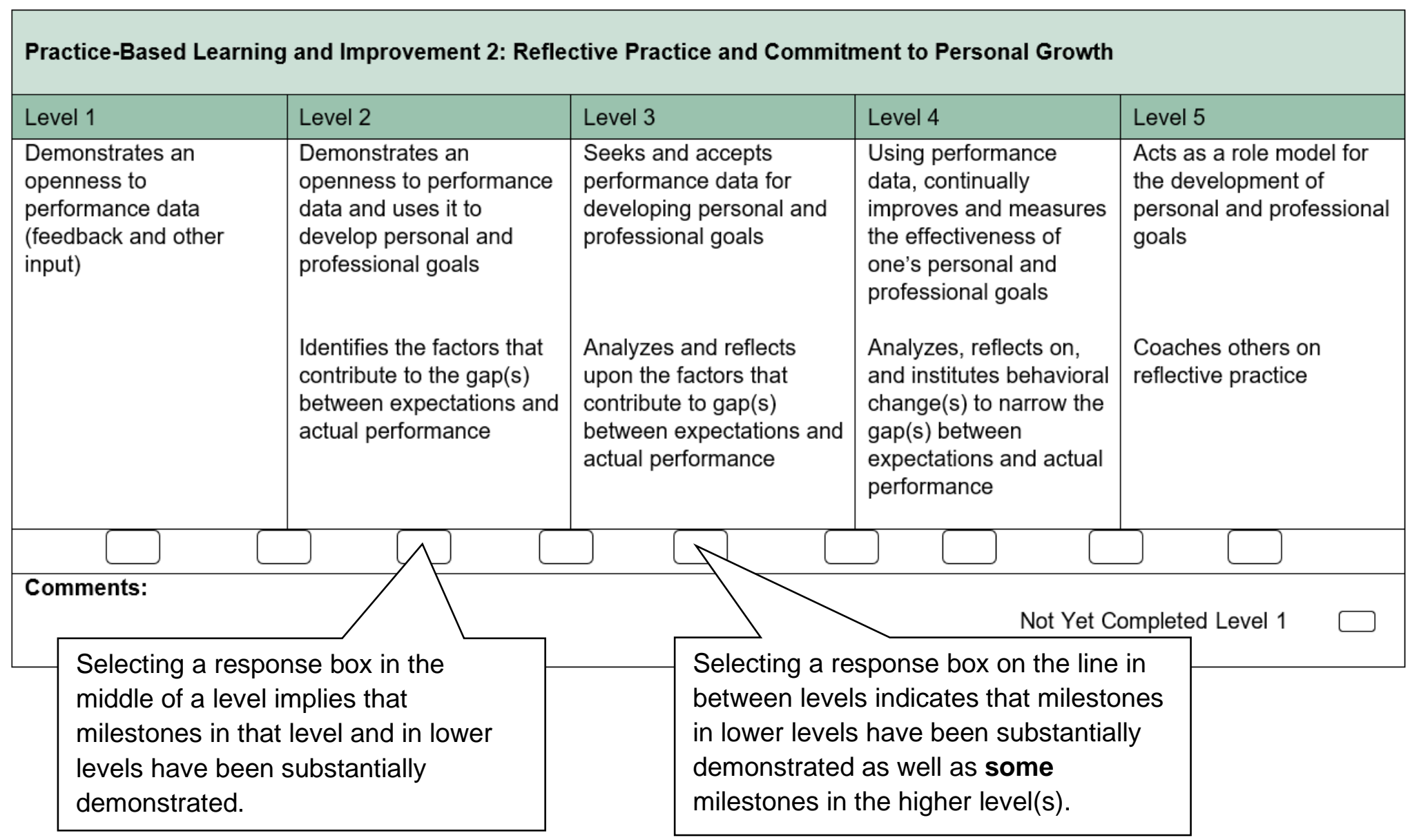




\section{Patient Care 1: Emergency Stabilization}

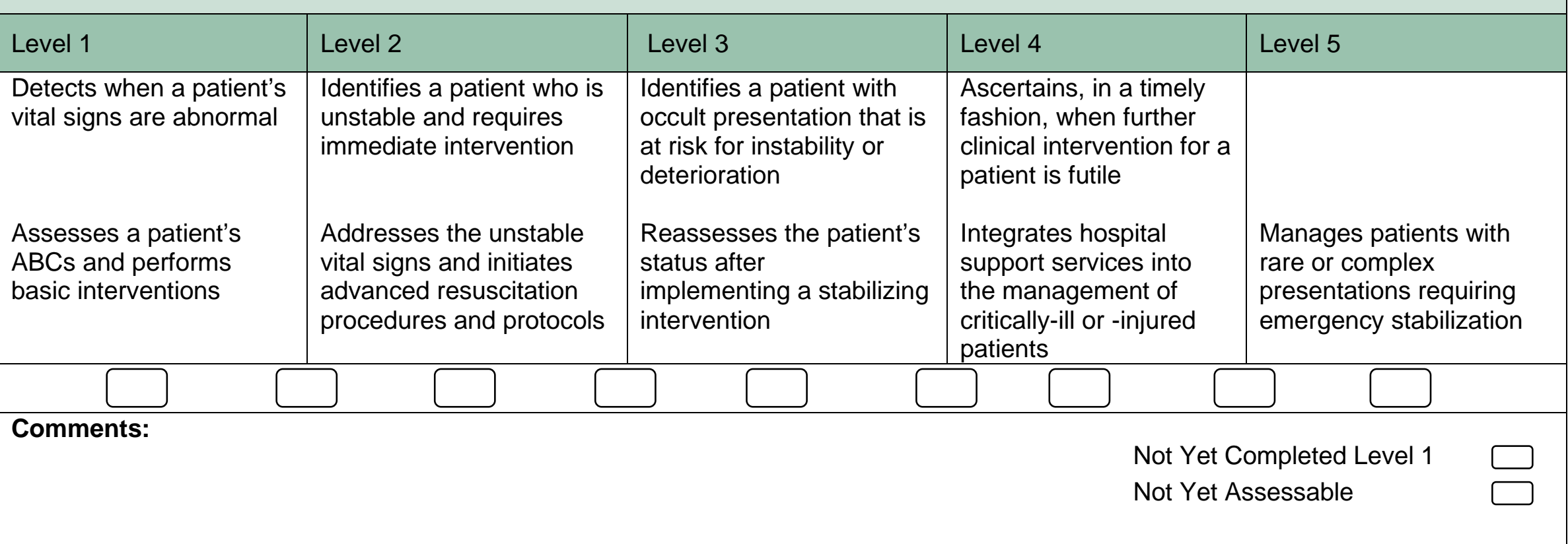




\section{Patient Care 2: Performance of a Focused History and Physical Exam}

\begin{tabular}{|l|l|l|l|l|}
\hline Level 1 & Level 2 & Level 3 & Level 4 & Level 5 \\
\hline $\begin{array}{l}\text { Elicits and } \\
\text { communicates a reliable } \\
\text { history and performs a } \\
\text { physical exam }\end{array}$ & $\begin{array}{l}\text { Elicits and communicates } \\
\text { a focused patient history } \\
\text { and performs a focused } \\
\text { physical exam that } \\
\text { effectively address the } \\
\text { patient's chief complaint } \\
\text { and urgent issues }\end{array}$ & $\begin{array}{l}\text { Prioritizes essential } \\
\text { components of a patient } \\
\text { history and physical } \\
\text { exam, given a limited or } \\
\text { dynamic circumstance }\end{array}$ & $\begin{array}{l}\text { Using all potential } \\
\text { sources of data, gathers } \\
\text { those that are necessary } \\
\text { for the beneficial } \\
\text { management of patients }\end{array}$ & $\begin{array}{l}\text { Models the effective use } \\
\text { of a patient history and } \\
\text { physical exam to } \\
\text { minimize the need for } \\
\text { further diagnostic testing }\end{array}$ \\
\hline Comments:
\end{tabular}




\section{Patient Care 3: Diagnostic Studies}

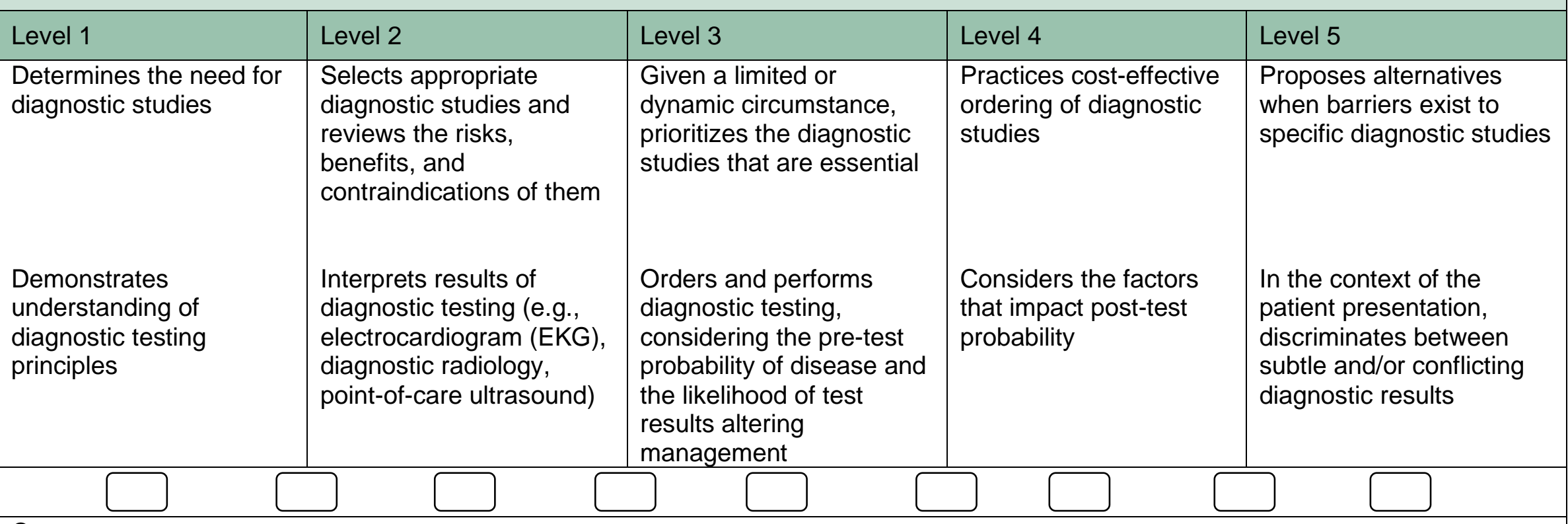

Comments:

Not Yet Completed Level 1 Not Yet Assessable 


\section{Patient Care 4: Diagnosis}

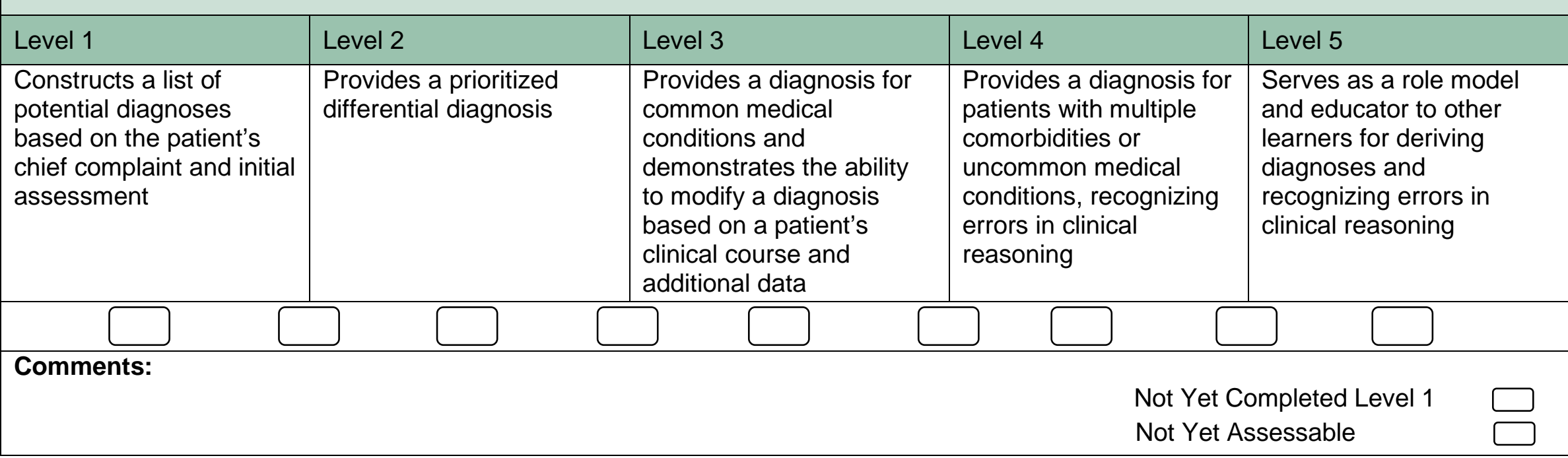




\section{Patient Care 5: Pharmacotherapy}

\begin{tabular}{|c|c|c|c|c|}
\hline Level 1 & Level 2 & Level 3 & Level 4 & Level 5 \\
\hline $\begin{array}{l}\text { Describes the different } \\
\text { classifications of } \\
\text { pharmacologic agents }\end{array}$ & $\begin{array}{l}\text { Selects appropriate agent } \\
\text { for therapeutic } \\
\text { intervention }\end{array}$ & $\begin{array}{l}\text { Considers array of drug } \\
\text { therapy and selects } \\
\text { appropriate agent based } \\
\text { on mechanism of action } \\
\text { and intended effect }\end{array}$ & $\begin{array}{l}\text { Selects the appropriate } \\
\text { agent based on patient } \\
\text { preferences, allergies, } \\
\text { cost, policies, and } \\
\text { clinical guidelines }\end{array}$ & $\begin{array}{l}\text { Participates in developing } \\
\text { departmental and/or } \\
\text { institutional policies on } \\
\text { pharmacy and } \\
\text { therapeutics }\end{array}$ \\
\hline $\begin{array}{l}\text { Consistently asks } \\
\text { patients for drug } \\
\text { allergies }\end{array}$ & $\begin{array}{l}\text { Evaluates for potential } \\
\text { adverse effects of } \\
\text { pharmacotherapy and } \\
\text { drug-to-drug interactions }\end{array}$ & $\begin{array}{l}\text { Recognizes and acts } \\
\text { upon common adverse } \\
\text { effects and interactions }\end{array}$ & $\begin{array}{l}\text { Recognizes and acts } \\
\text { upon uncommon and } \\
\text { unanticipated adverse } \\
\text { effects and interactions }\end{array}$ & \\
\hline \multicolumn{5}{|l|}{ Comments: } \\
\hline & & & \multirow{2}{*}{\multicolumn{2}{|c|}{$\begin{array}{l}\text { Not Yet Completed Level } 1 \\
\text { Not Yet Assessable }\end{array}$}} \\
\hline & & & & \\
\hline
\end{tabular}




\section{Patient Care 6: Reassessment and Disposition}

\begin{tabular}{|c|c|c|c|c|}
\hline Level 1 & Level 2 & Level 3 & Level 4 & Level 5 \\
\hline $\begin{array}{l}\text { Describes basic } \\
\text { resources available (e.g., } \\
\text { follow-up care, } \\
\text { rehabilitation, transfer } \\
\text { centers) }\end{array}$ & $\begin{array}{l}\text { Makes a disposition } \\
\text { decision for patients with } \\
\text { routine conditions } \\
\text { needing minimal } \\
\text { resources }\end{array}$ & $\begin{array}{l}\text { Makes a disposition } \\
\text { decision for patients with } \\
\text { routine conditions, with } \\
\text { resource utilization }\end{array}$ & $\begin{array}{l}\text { Makes disposition } \\
\text { decision for patients } \\
\text { with complex } \\
\text { conditions, with } \\
\text { resource utilization }\end{array}$ & $\begin{array}{l}\text { Participates in institutional } \\
\text { committees to develop } \\
\text { systems that enhance } \\
\text { safe patient disposition } \\
\text { and maximizes resources }\end{array}$ \\
\hline $\begin{array}{l}\text { Describes basic patient } \\
\text { education plans }\end{array}$ & $\begin{array}{l}\text { Educates patients on } \\
\text { simple discharge and } \\
\text { admission plans }\end{array}$ & $\begin{array}{l}\text { Educates patients } \\
\text { regarding diagnosis, } \\
\text { treatment plan, } \\
\text { medication review and } \\
\text { primary care } \\
\text { physician/consultant } \\
\text { appointments }\end{array}$ & $\begin{array}{l}\text { Educates patients on } \\
\text { complex discharge and } \\
\text { admission plans, } \\
\text { including complex } \\
\text { transfers }\end{array}$ & \\
\hline $\begin{array}{l}\text { Identifies the need for } \\
\text { patient re-evaluation }\end{array}$ & $\begin{array}{l}\text { Monitors that necessary } \\
\text { diagnostic and } \\
\text { therapeutic interventions } \\
\text { are performed }\end{array}$ & $\begin{array}{l}\text { Identifies which patients } \\
\text { will require ongoing } \\
\text { emergency department } \\
\text { evaluation and evaluates } \\
\text { the effectiveness of } \\
\text { diagnostic and } \\
\text { therapeutic interventions }\end{array}$ & $\begin{array}{l}\text { Evaluates changes in } \\
\text { clinical status during a } \\
\text { patient's emergency } \\
\text { department course }\end{array}$ & $\begin{array}{l}\text { Participates in the } \\
\text { development of protocols } \\
\text { to enhance patient safety }\end{array}$ \\
\hline Comments: & & & & \\
\hline & & & $\begin{array}{l}\text { Not Yet } \\
\text { Not Yet }\end{array}$ & $\begin{array}{l}\text { mpleted Level } 1 \\
\text { sessable }\end{array}$ \\
\hline
\end{tabular}




\section{Patient Care 7: Multitasking (Task-Switching)}

\begin{tabular}{|c|c|c|c|c|}
\hline Level 1 & Level 2 & Level 3 & Level 4 & Level 5 \\
\hline $\begin{array}{l}\text { Manages a single patient } \\
\text { amidst distractions }\end{array}$ & $\begin{array}{l}\text { Task-switches between } \\
\text { different patients of } \\
\text { similar acuity }\end{array}$ & $\begin{array}{l}\text { Employs task-switching in } \\
\text { an efficient manner to } \\
\text { manage multiple patients } \\
\text { of varying acuity and at } \\
\text { varying stages of work-up }\end{array}$ & $\begin{array}{l}\text { Employs task-switching } \\
\text { in an efficient manner to } \\
\text { manage the emergency } \\
\text { department }\end{array}$ & $\begin{array}{l}\text { Employs task switching in } \\
\text { an efficient manner to } \\
\text { manage the emergency } \\
\text { department under high- } \\
\text { volume or surge } \\
\text { situations }\end{array}$ \\
\hline \multicolumn{5}{|l|}{ Comments: } \\
\hline & & & \multicolumn{2}{|c|}{$\begin{array}{l}\text { Not Yet Completed Level } 1 \\
\text { Not Yet Assessable }\end{array}$} \\
\hline
\end{tabular}




\section{Patient Care 8: General Approach to Procedures}

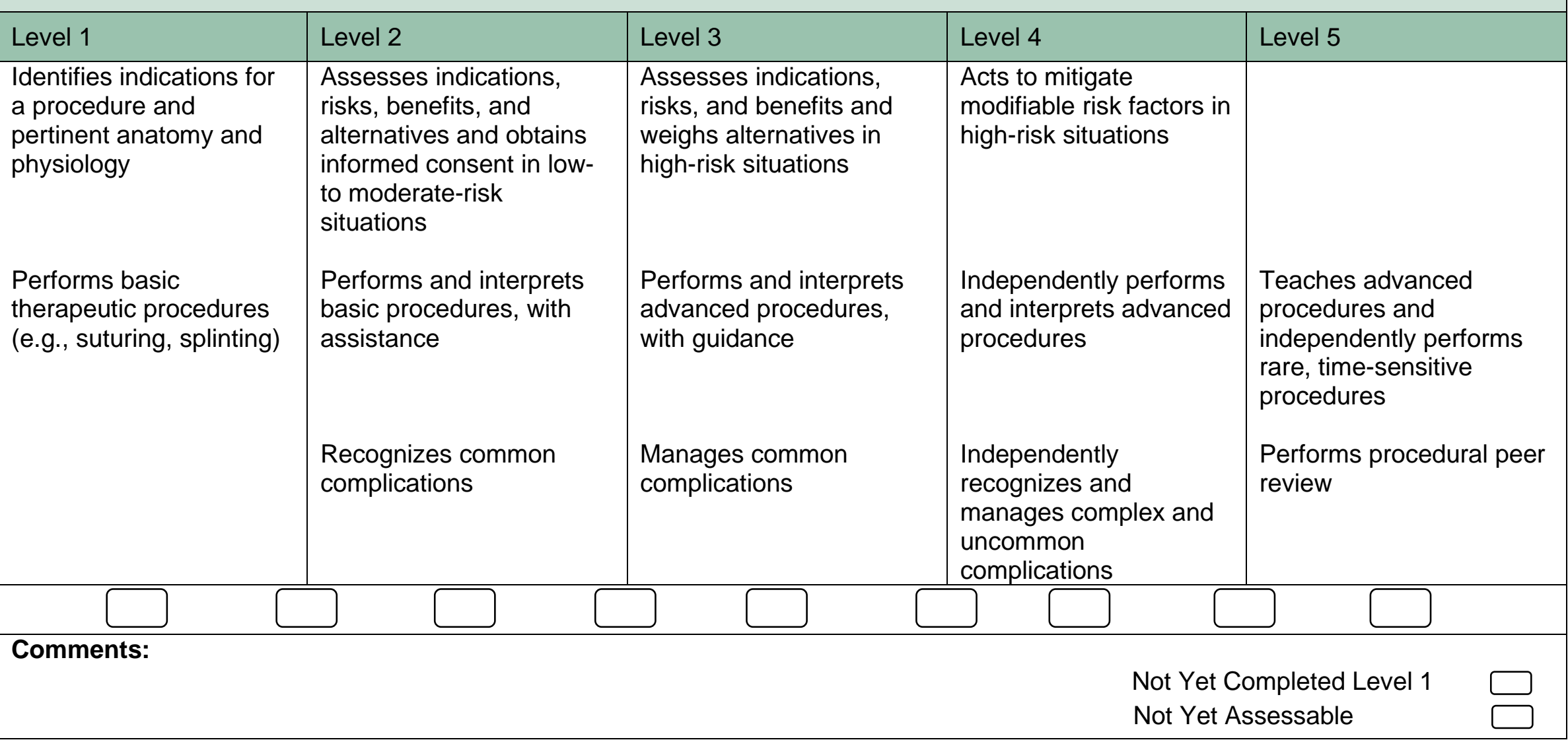




\section{Medical Knowledge 1: Scientific Knowledge}

\begin{tabular}{|l|l|l|l|l|}
\hline $\begin{array}{l}\text { Level 1 } \\
\begin{array}{l}\text { Demonstrates scientific } \\
\text { presentations and } \\
\text { conditions }\end{array}\end{array}$ & $\begin{array}{l}\text { Level 2 } \\
\text { knowledge of complex } \\
\text { presentations and } \\
\text { conditions }\end{array}$ & $\begin{array}{l}\text { Integrates scientific } \\
\text { knowledge of comorbid } \\
\text { conditions for complex } \\
\text { presentations }\end{array}$ & $\begin{array}{l}\text { Level 4 } \\
\text { knowledge of } \\
\text { uncommon, atypical, or } \\
\text { complex comorbid } \\
\text { conditions for complex } \\
\text { presentations }\end{array}$ & $\begin{array}{l}\text { Pursues and integrates } \\
\text { new and emerging } \\
\text { knowledge }\end{array}$
\end{tabular}

Comments:

Not Yet Completed Level 1 Not Yet Assessable 


\section{Medical Knowledge 2: Treatment and Clinical Reasoning}

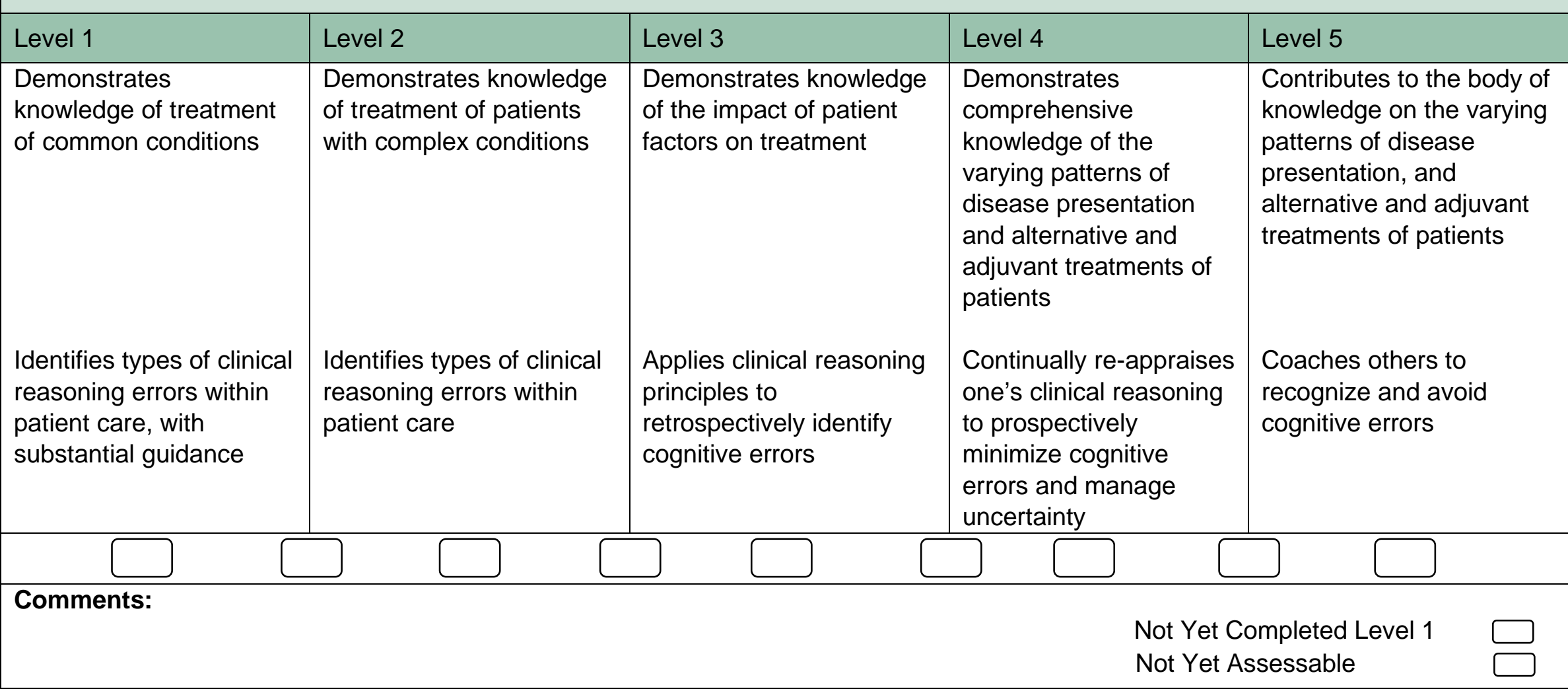




\section{Systems-Based Practice 1: Patient Safety}

\begin{tabular}{|l|l|l|l|l|}
\hline $\begin{array}{l}\text { Level 1 } \\
\begin{array}{l}\text { Demonstrates } \\
\text { patient safety events }\end{array}\end{array}$ & $\begin{array}{l}\text { Level 2 } \\
\text { that lead to patient safety } \\
\text { events }\end{array}$ & $\begin{array}{l}\text { Participates in analysis of } \\
\text { patient safety events } \\
\text { (simulated or actual) }\end{array}$ & $\begin{array}{l}\text { Level 4 } \\
\text { Conducts analysis of } \\
\text { patient safety events } \\
\text { and offers error } \\
\text { prevention strategies } \\
\text { (simulated or actual) }\end{array}$ & $\begin{array}{l}\text { Actively engages teams } \\
\text { and processes to modify } \\
\text { systems for preventing } \\
\text { patient safety events }\end{array}$ \\
$\begin{array}{l}\text { Demonstrates } \\
\text { knowledge of how to } \\
\text { report patient safety } \\
\text { events }\end{array}$ & $\begin{array}{l}\text { Reports patient safety } \\
\text { events through } \\
\text { institutional reporting } \\
\text { systems (simulated or } \\
\text { actual) }\end{array}$ & $\begin{array}{l}\text { Participates in disclosure } \\
\text { of patient safety events to } \\
\text { patients and families } \\
\text { (simulated or actual) }\end{array}$ & $\begin{array}{l}\text { Discloses patient safety } \\
\text { events to patients and } \\
\text { families (simulated or } \\
\text { actual) }\end{array}$ & $\begin{array}{l}\text { Acts as a role model } \\
\text { and/or mentor for others } \\
\text { in the disclosing of patient } \\
\text { safety events }\end{array}$ \\
\hline Comments:
\end{tabular}

Not Yet Completed Level 1 


\section{Systems-Based Practice 2: Quality Improvement}

\begin{tabular}{|l|l|l|l|l|}
\hline Level 1 & Level 2 & Level 3 & Level 4 & Level 5 \\
\hline $\begin{array}{l}\text { Demonstrates } \\
\text { knowledge of basic } \\
\text { quality improvement } \\
\text { methodologies and } \\
\text { metrics }\end{array}$ & $\begin{array}{l}\text { Describes local quality } \\
\text { improvement initiatives } \\
\text { (e.g., emergency } \\
\text { department throughput, } \\
\text { testing turnaround times) }\end{array}$ & $\begin{array}{l}\text { Participates in local } \\
\text { quality improvement } \\
\text { initiatives }\end{array}$ & $\begin{array}{l}\text { Demonstrates the skills } \\
\text { required for identifying, } \\
\text { developing, } \\
\text { implementing, and } \\
\text { analyzing a quality } \\
\text { improvement project }\end{array}$ & $\begin{array}{l}\text { Creates, implements, and } \\
\text { assesses quality } \\
\text { improvement initiatives at } \\
\text { the institutional or } \\
\text { community level }\end{array}$ \\
\hline Comments:
\end{tabular}




\section{Systems-Based Practice 3: System Navigation for Patient-Centered Care}

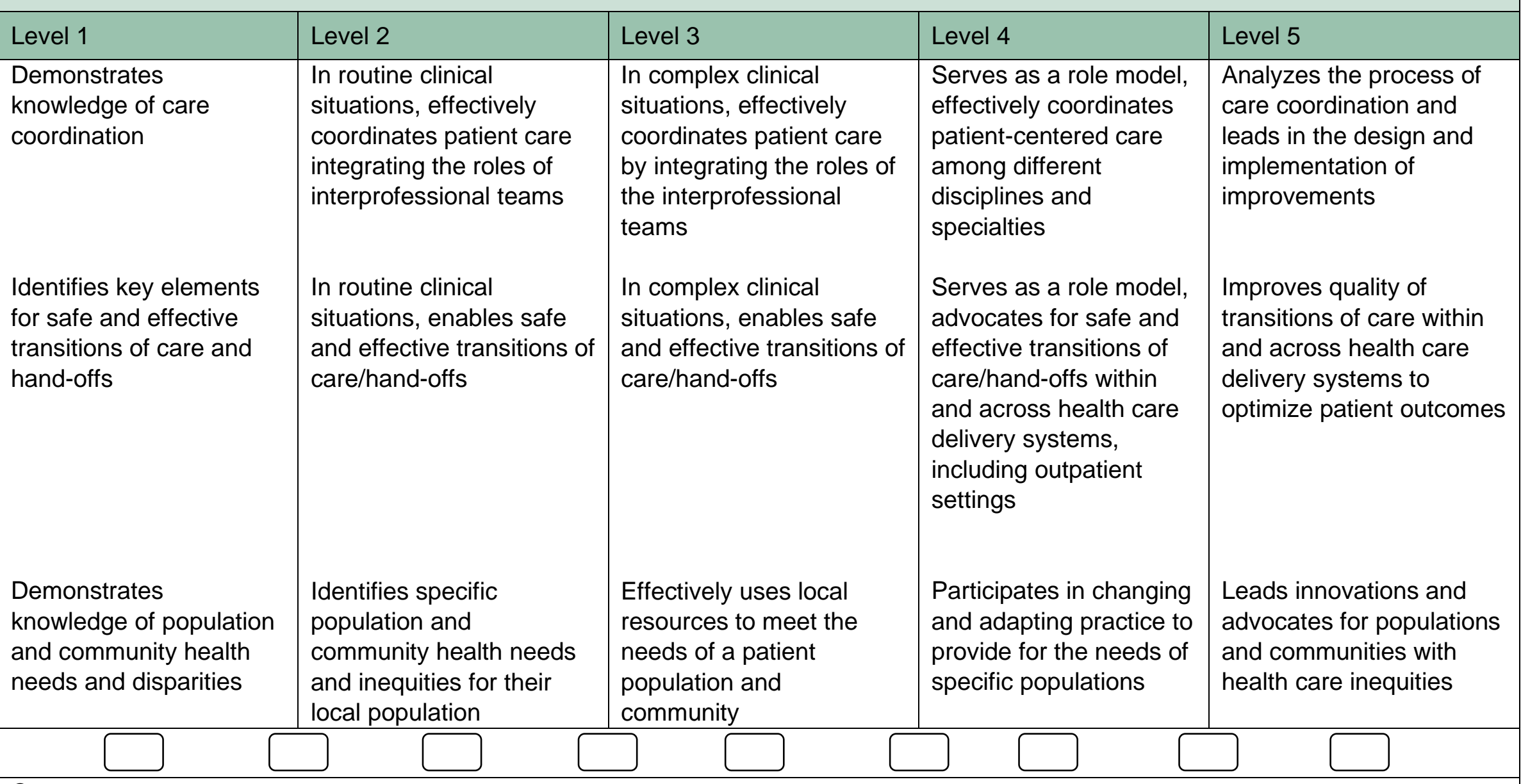

Comments: 


\section{Systems-Based Practice 4: Physician Role in Health Care Systems}

\begin{tabular}{|c|c|c|c|c|}
\hline \multirow[b]{2}{*}{$\begin{array}{l}\text { Level } 1 \\
\text { Identifies key } \\
\text { components of the } \\
\text { complex health care } \\
\text { system (e.g., hospital, } \\
\text { skilled nursing facility, } \\
\text { finance, personnel, } \\
\text { technology) }\end{array}$} & Level 2 & Level 3 & Level 4 & Level 5 \\
\hline & $\begin{array}{l}\text { Describes how } \\
\text { components of a complex } \\
\text { health care system are } \\
\text { interrelated, and how this } \\
\text { impacts patient care }\end{array}$ & $\begin{array}{l}\text { Discusses how individual } \\
\text { practice affects the } \\
\text { broader system (e.g., } \\
\text { length of stay, } \\
\text { readmission rates, clinical } \\
\text { efficiency) }\end{array}$ & $\begin{array}{l}\text { Manages various } \\
\text { components of the } \\
\text { complex health care } \\
\text { system to provide } \\
\text { efficient and effective } \\
\text { patient care and the } \\
\text { transition of care }\end{array}$ & $\begin{array}{l}\text { Advocates for or leads } \\
\text { systems change that } \\
\text { enhances high value, } \\
\text { efficient, and effective } \\
\text { patient care, and the } \\
\text { transition of care }\end{array}$ \\
\hline $\begin{array}{l}\text { Describes basic health } \\
\text { payment systems, } \\
\text { including (e.g., } \\
\text { government, private, } \\
\text { public, uninsured care) } \\
\text { practice models }\end{array}$ & $\begin{array}{l}\text { Delivers care with } \\
\text { consideration of each } \\
\text { patient's payment model } \\
\text { (e.g., insurance type) }\end{array}$ & $\begin{array}{l}\text { Engages patients in } \\
\text { shared decision making, } \\
\text { informed by each } \\
\text { patient's payment models }\end{array}$ & $\begin{array}{l}\text { Advocates for patient } \\
\text { care needs with } \\
\text { consideration of the } \\
\text { limitations of each } \\
\text { patient's payment } \\
\text { model }\end{array}$ & $\begin{array}{l}\text { Participates in health } \\
\text { policy advocacy activities }\end{array}$ \\
\hline & $\begin{array}{l}\text { Identifies basic } \\
\text { knowledge domains } \\
\text { required for medical } \\
\text { practice (e.g., information } \\
\text { technology, legal, billing, } \\
\text { coding, financial, and } \\
\text { personnel aspects) }\end{array}$ & $\begin{array}{l}\text { Demonstrates efficient } \\
\text { integration of information } \\
\text { technology required for } \\
\text { medical practice (e.g., } \\
\text { electronic health record, } \\
\text { documentation required } \\
\text { for billing and coding) }\end{array}$ & $\begin{array}{l}\text { Describes core } \\
\text { administrative } \\
\text { knowledge needed for } \\
\text { the transition to practice } \\
\text { (e.g., contract } \\
\text { negotiation, malpractice } \\
\text { insurance, government } \\
\text { regulation, compliance) }\end{array}$ & $\begin{array}{l}\text { Analyzes individual } \\
\text { practice patterns and } \\
\text { professional requirements }\end{array}$ \\
\hline & & & & \\
\hline
\end{tabular}

Comments:

Not Yet Completed Level 1 


\section{Practice-Based Learning and Improvement 1: Evidence-Based and Informed Practice}

\begin{tabular}{|l|l|l|l|l|}
\hline Level 1 & Level 2 & Level 3 & Level 4 & Level 5 \\
\hline $\begin{array}{l}\text { Demonstrates how to } \\
\text { eccess and use availablence }\end{array}$ & $\begin{array}{l}\text { Articulates the clinical } \\
\text { questions that are } \\
\text { necessary to guide } \\
\text { evidence-based care }\end{array}$ & $\begin{array}{l}\text { Locates and applies the } \\
\text { best available evidence, } \\
\text { integrating it with patient } \\
\text { preference, to the care of } \\
\text { complex patients }\end{array}$ & $\begin{array}{l}\text { Critically appraises and } \\
\text { applies evidence even } \\
\text { in the face of } \\
\text { uncertainty and of } \\
\text { conflicting evidence to } \\
\text { guide care that is } \\
\text { tailored to the individual } \\
\text { patient }\end{array}$ & $\begin{array}{l}\text { Coaches others to } \\
\text { critically appraise and } \\
\text { apply evidence for } \\
\text { complex patients, and/or } \\
\text { participates in the } \\
\text { development of guidelines }\end{array}$ \\
\hline Comments:
\end{tabular}




\section{Practice-Based Learning and Improvement 2: Reflective Practice and Commitment to Personal Growth}

\begin{tabular}{|c|c|c|c|c|}
\hline Level 1 & Level 2 & Level 3 & Level 4 & Level 5 \\
\hline $\begin{array}{l}\text { Demonstrates an } \\
\text { openness to } \\
\text { performance data } \\
\text { (feedback and other } \\
\text { input) }\end{array}$ & $\begin{array}{l}\text { Demonstrates an } \\
\text { openness to performance } \\
\text { data and uses it to } \\
\text { develop personal and } \\
\text { professional goals }\end{array}$ & $\begin{array}{l}\text { Seeks and accepts } \\
\text { performance data for } \\
\text { developing personal and } \\
\text { professional goals }\end{array}$ & $\begin{array}{l}\text { Using performance } \\
\text { data, continually } \\
\text { improves and measures } \\
\text { the effectiveness of } \\
\text { one's personal and } \\
\text { professional goals }\end{array}$ & $\begin{array}{l}\text { Acts as a role model for } \\
\text { the development of } \\
\text { personal and professional } \\
\text { goals }\end{array}$ \\
\hline
\end{tabular}

Comments:

Not Yet Completed Level 1 


\section{Professionalism 1: Professional Behavior and Ethical Principles}

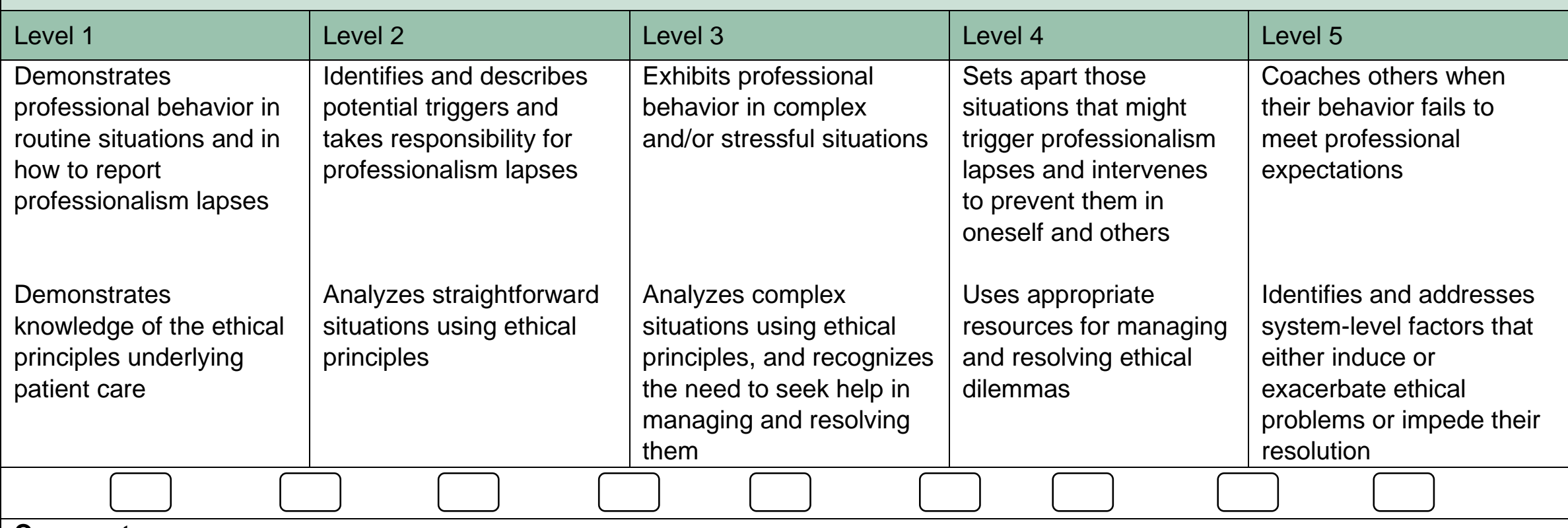

Comments:

Not Yet Completed Level 1 


\section{Professionalism 2: Accountability/Conscientiousness}

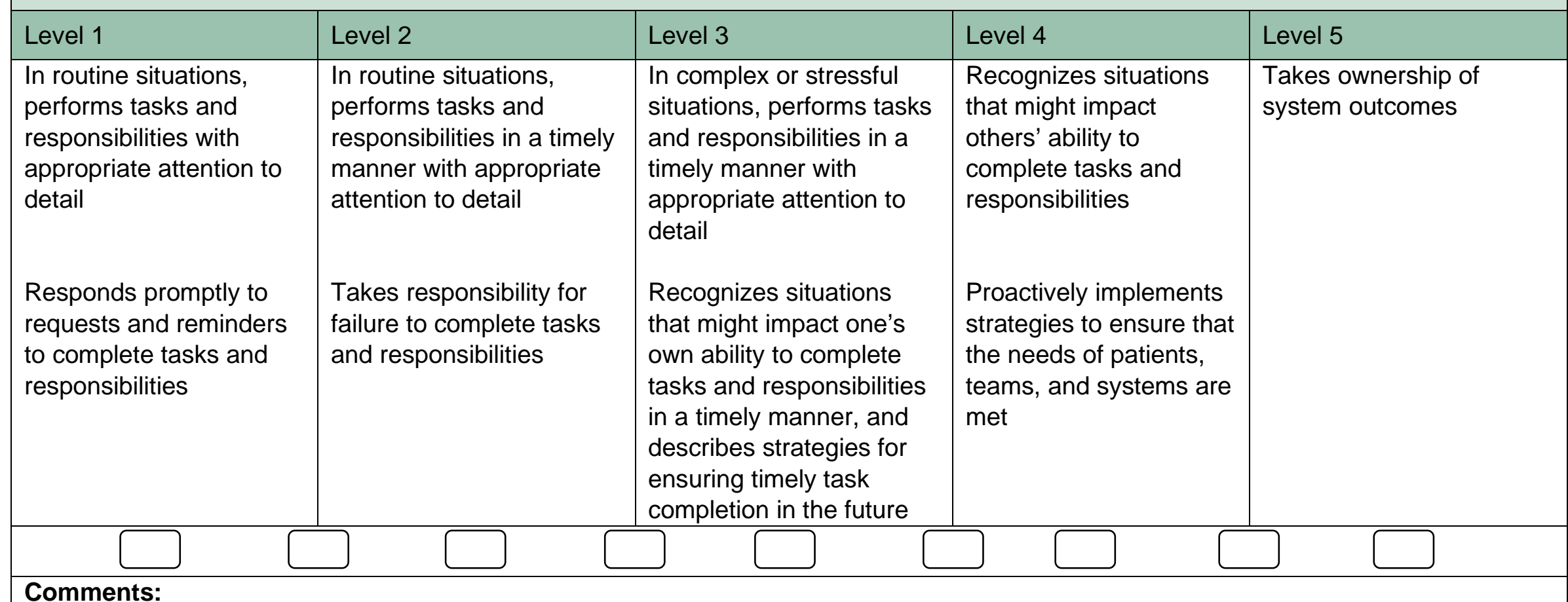

Not Yet Completed Level 1 


\section{Professionalism 3: Self-Awareness and Well-Being}

\begin{tabular}{|l|l|l|l|l|}
\hline Level 1 & Level 2 & Level 3 & Level 4 & Level 5 \\
\hline $\begin{array}{l}\text { Recognizes, with } \\
\text { assistance, the status of } \\
\text { one's personal and } \\
\text { professional well-being }\end{array}$ & $\begin{array}{l}\text { Independently recognizes } \\
\text { the status of one's } \\
\text { personal and professional } \\
\text { well-being and engages in } \\
\text { help-seeking behaviors }\end{array}$ & $\begin{array}{l}\text { With assistance, } \\
\text { proposes a plan to } \\
\text { optimize personal and } \\
\text { professional well-being }\end{array}$ & $\begin{array}{l}\text { Independently develops } \\
\text { a plan to optimize one's } \\
\text { personal and } \\
\text { professional well-being }\end{array}$ & $\begin{array}{l}\text { Coaches others when } \\
\text { their emotional responses } \\
\text { or level of } \\
\text { knowledge/skills fail to } \\
\text { meet professional } \\
\text { expectations }\end{array}$
\end{tabular}

This subcompetency is not intended to evaluate a resident's well-being. Rather, the intent is to ensure that each resident has the fundamental knowledge of factors that affect well-being, the mechanisms by which those factors affect well-being, and available resources and tools to improve well-being. 


\section{Interpersonal and Communication Skills 1: Patient- and Family-Centered Communication}

\begin{tabular}{|c|c|c|c|c|}
\hline Level 1 & Level 2 & Level 3 & Level 4 & Level 5 \\
\hline \multirow{2}{*}{$\begin{array}{l}\text { Uses language and non- } \\
\text { verbal behavior to reflect } \\
\text { respect and establish } \\
\text { rapport while accurately } \\
\text { communicating one's own } \\
\text { role within the health care } \\
\text { system } \\
\text { Identifies common } \\
\text { barriers to effective } \\
\text { communication (e.g., } \\
\text { language, disability) }\end{array}$} & $\begin{array}{l}\text { Establishes a therapeutic } \\
\text { relationship in } \\
\text { straightforward encounters } \\
\text { with patients using active } \\
\text { listening and clear } \\
\text { language }\end{array}$ & $\begin{array}{l}\text { Establishes a therapeutic } \\
\text { relationship } \\
\text { in challenging patient } \\
\text { encounters }\end{array}$ & $\begin{array}{l}\text { Easily establishes } \\
\text { therapeutic relationships } \\
\text { with patients, regardless } \\
\text { of the complexity of } \\
\text { cases }\end{array}$ & \multirow[t]{2}{*}{$\begin{array}{l}\text { Acts as a mentor to others } \\
\text { in situational awareness } \\
\text { and critical self-reflection } \\
\text { with the aim of consistently } \\
\text { developing positive } \\
\text { therapeutic relationships } \\
\text { and minimizing } \\
\text { communication barriers }\end{array}$} \\
\hline & $\begin{array}{l}\text { Identifies complex barriers } \\
\text { to effective communication } \\
\text { (e.g., health literacy, } \\
\text { cultural, technology) }\end{array}$ & $\begin{array}{l}\text { When prompted, reflects } \\
\text { on one's personal biases, } \\
\text { while attempting to } \\
\text { minimize communication } \\
\text { barriers }\end{array}$ & $\begin{array}{l}\text { Independently } \\
\text { recognizes personal } \\
\text { biases of patients, while } \\
\text { attempting to proactively } \\
\text { minimize communication } \\
\text { barriers }\end{array}$ & \\
\hline $\begin{array}{l}\text { With insight gained } \\
\text { through an assessment of } \\
\text { patient/family } \\
\text { expectations coupled with } \\
\text { an understanding of their } \\
\text { health status and } \\
\text { treatment options, adjusts } \\
\text { one's communication } \\
\text { strategies }\end{array}$ & $\begin{array}{l}\text { Organizes and initiates } \\
\text { communication with a } \\
\text { patient/family by clarifying } \\
\text { expectations and verifying } \\
\text { one's understanding of the } \\
\text { clinical situation }\end{array}$ & $\begin{array}{l}\text { With guidance, sensitively } \\
\text { and compassionately } \\
\text { delivers medical } \\
\text { information to patients, } \\
\text { elicits patient/family values, } \\
\text { learns their goals and } \\
\text { preferences, and } \\
\text { acknowledges uncertainty } \\
\text { and conflict }\end{array}$ & $\begin{array}{l}\text { Independently uses } \\
\text { shared decision making } \\
\text { with a patient/family to } \\
\text { align their values, goals, } \\
\text { and preferences with } \\
\text { potential treatment } \\
\text { options and ultimately to } \\
\text { achieve a personalized } \\
\text { care plan }\end{array}$ & $\begin{array}{l}\text { Acts as a role model to } \\
\text { exemplify shared decision } \\
\text { making in patient/family } \\
\text { communication that } \\
\text { embodies various degrees } \\
\text { of uncertainty/conflict }\end{array}$ \\
\hline & & & & \\
\hline
\end{tabular}

Comments:

Not Yet Completed Level 1 


\section{Interpersonal and Communication Skills 2: Interprofessional and Team Communication}

\begin{tabular}{|c|c|c|c|c|}
\hline Level 1 & Level 2 & Level 3 & Level 4 & Level 5 \\
\hline $\begin{array}{l}\text { Respectfully requests a } \\
\text { consultation }\end{array}$ & $\begin{array}{l}\text { Clearly and concisely } \\
\text { requests a consultation or } \\
\text { other resources for } \\
\text { patient care }\end{array}$ & $\begin{array}{l}\text { Integrates } \\
\text { recommendations made } \\
\text { by various members of } \\
\text { the health care team to } \\
\text { optimize patient care }\end{array}$ & $\begin{array}{l}\text { Acts as a role model for } \\
\text { flexible communication } \\
\text { strategies, i.e., those } \\
\text { strategies that value } \\
\text { input from all health } \\
\text { care team members } \\
\text { and that resolve conflict } \\
\text { when needed }\end{array}$ & \\
\hline $\begin{array}{l}\text { Uses language that } \\
\text { reflects the values all } \\
\text { members of the health } \\
\text { care team }\end{array}$ & $\begin{array}{l}\text { Communicates } \\
\text { information effectively } \\
\text { with all health care team } \\
\text { members }\end{array}$ & $\begin{array}{l}\text { Engages in active } \\
\text { listening to adapt to the } \\
\text { communication styles of } \\
\text { the team }\end{array}$ & $\begin{array}{l}\text { Uses effective } \\
\text { communication to lead } \\
\text { or manage health care } \\
\text { teams }\end{array}$ & $\begin{array}{l}\text { Acts as a role model for } \\
\text { communication skills } \\
\text { necessary to lead or } \\
\text { manage health care } \\
\text { teams }\end{array}$ \\
\hline & & & & \\
\hline
\end{tabular}

Comments: 


\section{Interpersonal and Communication Skills 3: Communication within Health Care Systems}

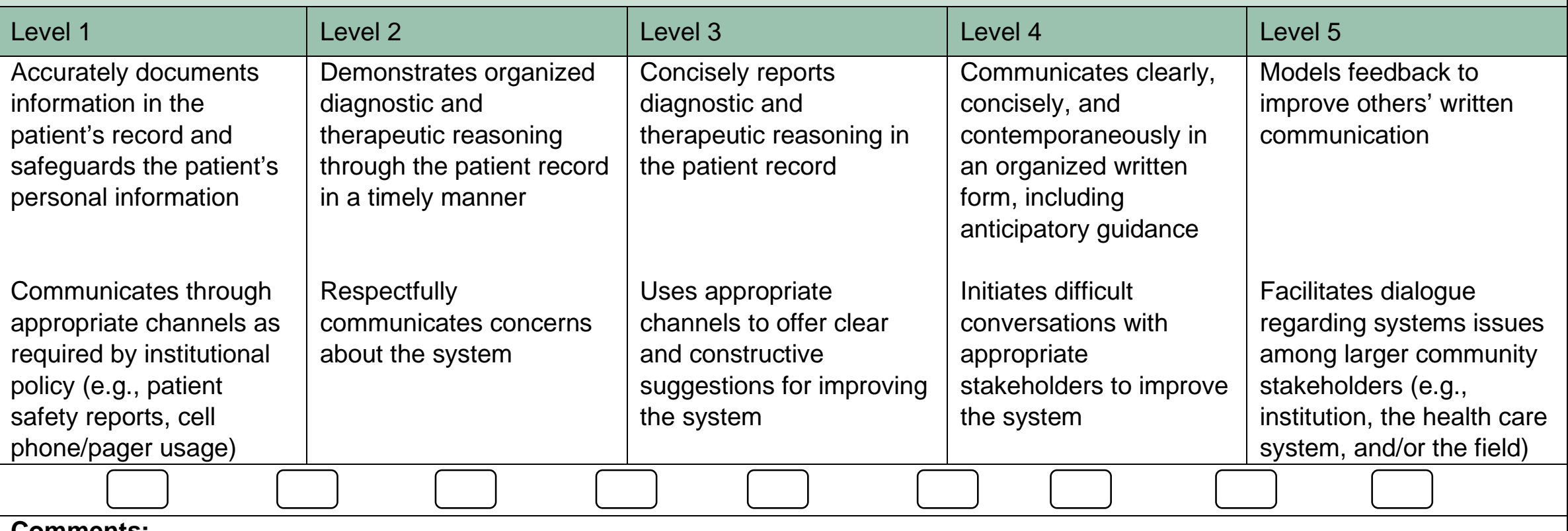

Comments:

Not Yet Completed Level 1 